\title{
EARLY ONSET OF MODERN-STYLE SHELL BEDS IN THE PERMIAN SEQUENCES OF THE PARANÁ BASIN: IMPLICATIONS FOR THE PHANEROZOIC TREND IN BIOCLASTIC ACCUMULATIONS
}

\author{
MARCELLO GUIMARAES SIMÕES ${ }^{1}$, MICHAL KOWALEWSKI ${ }^{2}$, FERNANDA DE FREITAS TORELLO ${ }^{1}$, \\ RENATO PIRANI GHILARDI ${ }^{3}$ AND LUIZ HENRIQUE CRUZ DE MELLO ${ }^{3}$
}

\begin{abstract}
The internal characteristics and stratigraphic distribution of Permian shell beds from the sedimentary sequences of the Paraná basin were analyzed quantitatively. Taphonomic, sedimentologic, and stratigraphic data from 23 geological sections and 32 outcrops were amassed for the total of 32 fossil concentrations found in the stratigraphic sequence of the Passa Dois Group (Intervals 1-4 of Rohn's lithobiostratigraphic framework). The biostratinomic analysis of bioclastic concentrations (including clast composition, geometry, thickness/ traceability, close-packing, internal complexity, and taphonomic signatures) reveals that the shell beds group into two distinct "biostratinomic styles" or "shellbed modes" of Kidwell's classification: Archaic and Modern. Archaic shell beds $(29.4 \%)$ are thin $(>3 \mathrm{~cm})$, two-dimensional, internally simple concentrations (distal tempestites), with disperse, high-organic nacreous aragonitic shells of anomalodesmatan bivalves. Modern shell beds $(70.6 \%)$ are thick $(30-50 \mathrm{~cm})$, fully three-dimensional, internally complex, amalgamated concentrations (bioclastic sandstones or coquinas interpreted as proximal tempestites) with a mixture of densely-packed, crossed calcitic (?) shells of veneroid bivalves, and shells of anomalodesmatan bivalves. Archaic shell beds dominate $(100 \%, n=8)$ the distal lithofacies of Passa Dois Group (Serra Aha Formation; Interval 1), whereas Modern shell beds are abundant in the more proximal lithofacies (Teresina/Corumbataí Formations) of Intervals 2 ( $81.25 \%$, $\mathrm{n}=13), 3(100 \%, \mathrm{n}=1)$, and $4(88.9 \%, \mathrm{n}=8)$. The increase in shellbed thickness and internal complexity in Intervals 2 - 4 (the latest Late Permian) appears to be tied to lithologic changes (changes in tempestite proximity), suggesting that the trend is controlled primarily by physical factors. A biologic control is also suggested, however, because the thick coquinas of Modern Type are invariably composed of low organic (crossed), veneroid shells of Pinzonella illusa and Pinzonella neotroplca. The high proportion of infaunal bivalves (anomalodesmatans, veneroids) indicates that the Permian benthic association was ecologically post-Paleozoic rather than Paleozoic. The shell beds from the Paraná basin suggest that the transition from the Archaic to Modern type of shell beds and the shift from Paleozoic to more modern ecology may have both started already in the late Paleozoic.

Keywords: Taphonomy, Biostratinomy, Fossil Record, Permian, Bivalves, Paraná basin
\end{abstract}

INTRODUCTION Shell beds, densely packed concentrations of bioskeletal remains, are a conspicuous feature of the Phanerozoic stratigraphic record and an important (often unique) source of paleobiological information. Recent studies have demonstrated that the internal complexity and thickness of shell beds have changed notably throughout the Phanerozoic (Kidwell 1990, Kidwell \& Brenchley 1994, 1996, Li \& Droser 1997). The comparison of the OrdovicianSilurian, Jurassic and Neogene shell beds indicated a significant increase in their internal complexity and thickness toward the Cenozoic (Kidwell 1990, Kidwell \& Brenchley 1994,1996). Similarly, Li \& Droser (1997) observed that the rapid increase in thickness of Cambrian fossil concentrations was tied not only to lithologic changes but also to the appearance of new clades of trilobites. Most likely, the increase in the thickness and complexity of shell beds reflects the longterm increase in (1) the macrofauna diversity, (2) the average body size of benthos, (3) the depth and intensity of infaunalization, (4) the durability of biomineralized skeletons, and (5) the occupation of highenergy habitats (Kidwell 1990, Kidwell \& Brenchley 1996). The last two factors $(4 \& 5)$ may have played the most important role (Kidwell \& Brenchley 1996). Regardless of the relative importance of the various factors, the characteristics of the marine bioclastic accumulations are, at least partly, a function of ecology and diversity of the marine benthos. The secular changes in those characteristics are likely to have been associated with secular changes in the nature of marine benthic ecosystems.

Although the recent studies reveal important trends in post-mortem shell accumulations, the data for some critical intervals are still lacking. In particular, the late Paleozoic is poorly studied. This study focuses on the Permian siliciclastic sequences of the Paraná basin, Brazil. This sequence is a particularly attractive target for studying the secular trends and causative factors underlying the Phanerozoic history of shell beds. First, the studied interval corresponds to the critical temporal gap in our knowledge of the fossil record of shell beds. Second, the shell beds are all dominated by bivalve mollusks (i.e., one key biostratinomic variable [type of bioclasts] is kept constant). Third, the studied units coincide with the time interval when two groups of specialized infaunal bivalves (Anomalodesmata and Veneroida) diversified rapidly in the region (Simões et al. 1998); although belonging to the same ecological guild, the two groups differ in shell mineralogy and microstructure. Finally, taphonomic studies (Simões \& Kowalewski 1998) suggest that the origin and composition of these fossil concentrations may have been tied to both physical and biological parameters. The shell beds of the Paraná basin are ideal to study the late Paleozoic history of bioclastic accumulations.

GEOLOGICAL SETTING AND FIELD AREA The studied lithostratigraphic units belong to the Passa Dois Group deposited in the Paraná basin during the Late Paleozoic (Rohn 1994). The units are the upper part of a major transgressive-regressive cycle (about $70 \mathrm{Ma}$ ) defined by regionally traceable unconformities (Fig. 1). Shell beds are very sparse in the transgressive part the cycle. Most likely, this is due to the dominance of anoxic facies in deeper parts of the basin coupled with the subsequent (Cenozoic) erosion of the more oxygenated, proximal facies along the basin margins (Simões et al. 1998). The regressive portion of the cycle (Fig. 1) consists of the upper (Late Permian) units of the Passa Dois Group (Serra Alta, Teresina/ Corumbataí and Rio do Rasto formations). During the late transgressive and regressive phase, increasingly stable tectonic settings and widespread epeiric conditions (Simões et al. 1998, Riccomini 1995) characterized the basin. The bivalve-dominated shell beds are much more common and widespread in this part of the cycle.

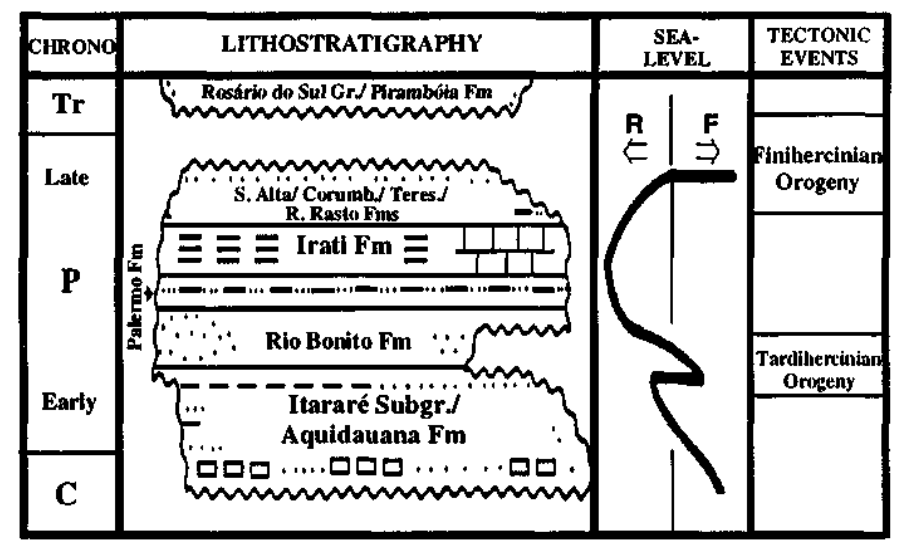

Figure 1 - Chronolithostratigraphic chart for the Paraná basin (after Zaldn et al. 1991). Abbreviation of the formation names are as follows: S. Alta Serra Alta; Corumb. = Corumbatai; Teres. $=$ Teresina $;$ R. do Rasto - Rio do Rasto. 
Stratigraphy and environmental setting of the Passa Dois Group The Passa Dois Group (sensu Rohn 1994) represents a coarsening-upward sequence and includes the Irati, Serra Alta, Teresina/Corumbataí, and Rio do Rasto formations (Fig. 1). The Irati Formation records the maximum flooding in the Late Paleozoic of the Paraná basin (Fig. 1) with its black shales representing a basin-wide euxinic episode. The shales are contemporaneous with shallow-marine, carbonate-platform deposits formed, at least partly, under hypersaline conditions (Santos Neto \& Cerqueira 1993, Hachiro 1996). This phase was unfavorable for the development of benthic communities (Simões et al. 1998). During the subsequent (Teresina/Corumbataí) phase, the marginal shallow water settings may have been predominately hypersaline (Rohn 1994, Matos 1995), but punctuated by storm events (Rohn 1994, Simões et al. 1996, 1998). Additionally, non-marine ostracodes (Sohn \& Rocha-Campos 1990) of the Corumbatai Formation suggest a notable fluvial influence, which must have lowered intermittently the salinity along the northern margin of the Paraná basin and may have resulted in strong salinity variations in the near shore environments. The low diversity levels in the bivalve associations make the Permian ecosystems of the Paraná basin somewhat analogous to the modern Baltic Sea (Simões \& Kowalewski 1998).

Study area This study was conducted at the eastern margin of the Paraná basin: the São Paulo State area (Fig. 2). The three areas (southwestern, central, and northeastern) of the São Paulo State (Fig. 2) are particularly rich in outcrops with well-exposed, bivalvedominated shell beds of the Serra Alta and Teresina/Corumbataí formations. The localities that provided the bulk of the field data are shown on Figure 2. The Passa Dois Group deposits of the São Paulo State area can be divided into 4 distinct intervals that represent minor (higher-order) transgressive-regressive cycles (Fig. 3) contained within the generally regressive trend (Rohn 1994). Interval 1 (Serra Alta Formation and the base of the Corumbataí Formation) represents the transgression terminated with the deposition of Interval 2 (Rohn 1994). A new sea level rise is recorded by Interval 3, whereas most of the deposits of Interval 4 accumulated under generally regressive conditions. Intervals 2 - 4 all belong to the Teresina/Corumbataí formations.

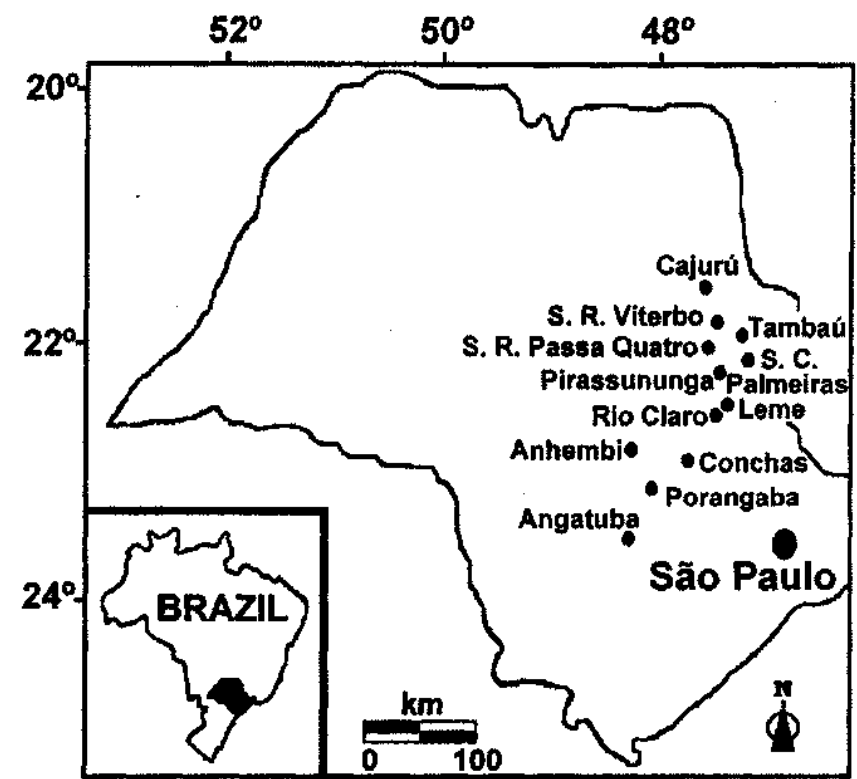

Figure 2 - Schematic map of the São Paulo State area showing the geographic position of the studied localities.

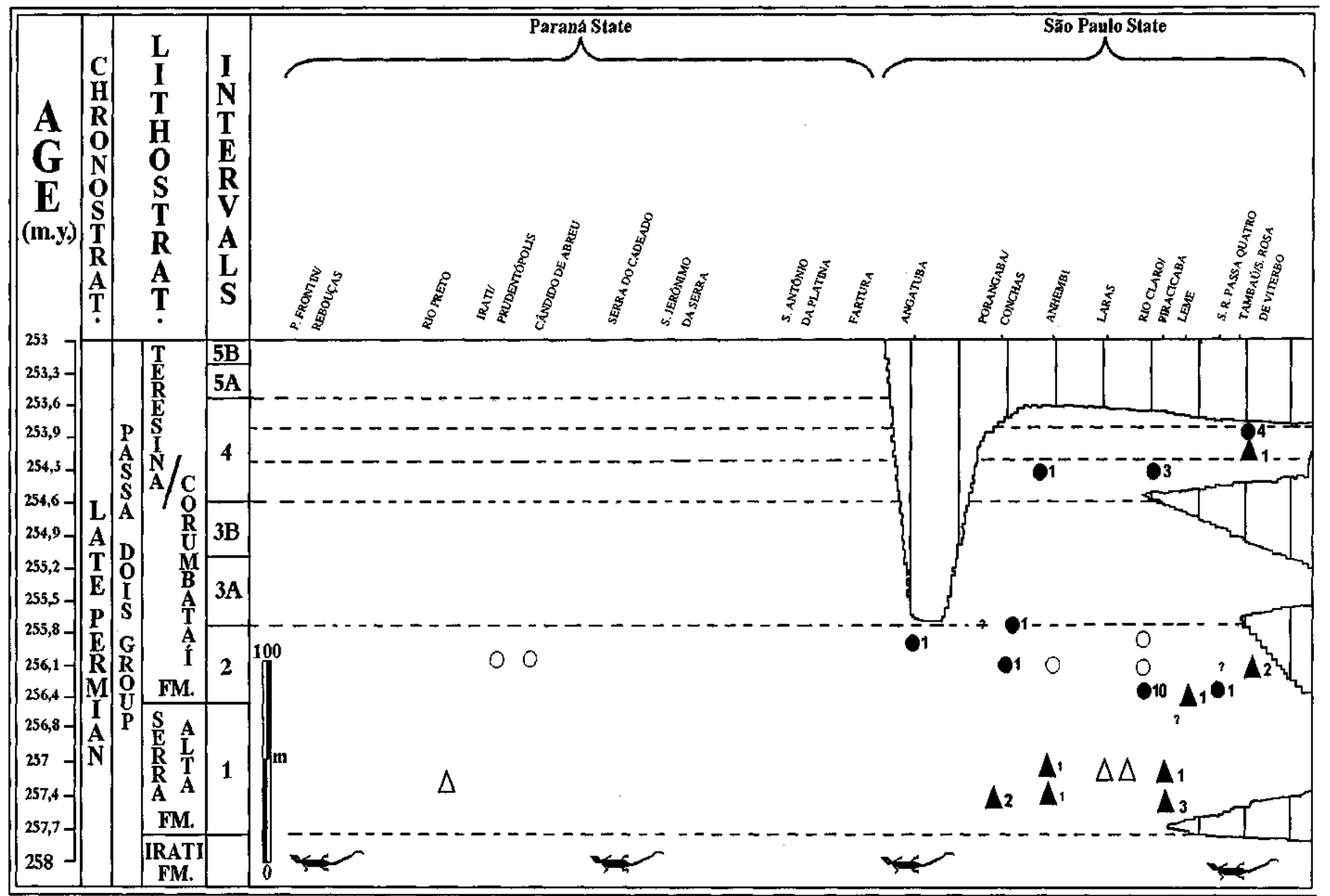

Figure 3 - Chronolithostratigraphic chart for the Passa Dois Group (modified from Rohn 1994). Explanation: triangles: Archaic shell beds: Circles: Modern shell beds. Black symbols indicate the field data; white symbols mark shell beds categorized using literature data. The numbers associated with symbols indicate the number of fossil concentration at a given site. Shell beds with uncertain stratigraphic position are marked as "? ". 
MATERIAL AND METHODS We have described shell beds following the approach of Kidwell (1990), Kidwell \& Brenchley $(1994,1996)$ and Li \& Droser (1997). Although literature information also have been used, the overwhelming majority of data came from original field observations $(94 \%, n=32)$. Twenty-three geological sections and thirty-two outcrops were examined. Additionally, we have examined the material housed in two different scientific collections (Univ. of São Paulo State and Univ. of São Paulo). The data collected for this analysis were collected from the same set of strata, for which their current biostratigraphic scheme was developed (Rohn 1994). The studied units include Intervals 1-4 discussed above.

Thirty-two bivalve-dominated concentrations where examined in the field for their composition, geometry, thickness/traceability, closepacking, and internal complexity (Kidwell \& Holland 1991). Following the initial analysis in the field, large blocks were collected $\left(-0.05 \mathrm{~m}^{3}\right.$ each) and transported to the Laboratory of Paleontology of Botucatu, State of São Paulo. Subsequently, the concentrations were cleaned and prepared using water, acetic acid, and mechanical tools (for more details see Simões \& Kowalewski 1998).

The systematic classification of Simões et al. (1997) and Mello (1999) was used to identify bivalve species, and their mode of life was inferred on the basis of their functional morphology (Ghilardi 1999). The examined fossil concentrations were categorized by their physical dimension, taxonomic composition, and taphonomic signatures and classified into two biostratinomic styles: "Archaic" and "Modern" (sensu Kidwell 1990). The distribution of the shell beds was then interpreted in the context of the regional chronolithostratigraphic framework of the Passa Dois Group (sensuRohn 1994). This regional scheme allows for reliable intrabasinal correlation of the analyzed strata, which is sufficient for the objectives of this study (the correlation of the units to the global international standard is approximate and will not be discussed here).

RESULTS Fossil accumulations showing "Archaic" and "Modern" biostratinomic styles are both present in the Passa Dois Group (Serra Alta, Teresina/Corumbataf formations) (Table 1). Archaic shell beds $(29.5 \%)$ are thin $(<3 \mathrm{~cm})$, two-dimensional, internally simple concentrations (distal tempestites), with disperse, high-organic nacreous aragonitic shells of anomalodesmatan bivalves. Most of the shells are disarticulated with low degrees of abrasion and fragmentation. Bioclasts are typically concordant with the bedding plane. In contrast, Modern shell beds $(70.5 \%)$ are thick $(30-50 \mathrm{~cm})$, fully three-dimensional, internally complex, amalgamated concentrations with a mixture of densely packed, crossed calcitic (?) shells of veneroid, and high-organic nacreous aragonitic shells of anomalodesmatans (proximal tempestites). Specific examples of such multi-event concentrations are described in detail elsewhere (Simões \& Kowalewski 1998, Simões et al. 1996, Torello 1991). The fauna contained within the Modern shell beds tends to be more diversified than that found in the Archaic beds. The Modern beds include up to at least 8 bivalve species dominated by infaunal taxa including Pinionella illusa Reed, 1932, Pinzonella neotropica (Reed), 1928 or
Terraiopsis aequilateralis (Mendes), 1952. The most distinct feature of the Modern beds is their internal complexity, indicating multi-event genesis and extensive time-averaging. For example, the Ferraz Shell Bed (Simões \& Kowalewski 1998) consists of four distinct sub-units that include a lag concentration, a partly reworked storm deposit, a rapidly deposited sandstone unit, and a winnowed shell-rich horizon buried by a storm-induced obruption deposit. The Tambau Shell Bed (Torello 1999) offers other example of an amalgamated coquina capped by a horizon of semi-infaunal byssate bivalves (Naiadopsis lamellosus Mendes 1952) preserved in life position.

The vertical and horizontal distribution of the examined concentrations is strikingly non-random (Tab. 1, Fig. 3). The Archaic beds are common $(100 \%, \mathrm{n}=8)$ in the lower part of the studied sequence (Interval 1 sensu Rohn 1994), but only few occurrences of the Archaic type are known from Intervals 2-4 (Tab. 1). In the latter units, shell beds are dominated overwhelmingly by the Modern-style concentrations: Interval $2(81.25 \%, n=13)$, Interval $3(100 \%, n=1)$, and Interval $4(88.9 \%, \mathrm{n}=8)$.

\section{DISCUSSION AND CONCLUSIONS Factors controlling the distribution and genesis of the shell beds The} striking distribution trend of the Archaic and Modern shell beds (Fig. 4) may reflect the physical changes due to the regressive trend and/or ecological changes related to the geologically rapid diversification of infaunal bivalves.

Several authors suggested (e.g., Sousa etal. 1991, Rohn 1994) that the predominantly massive, clay-rich siltstones and silty shales, where Archaic concentrations are common, were deposited in distal offshore settings, occasionally disrupted by storm events. These settings were conducive to the formation of thin, single-event shell concentrations (distal tempestites). The subsequent regressive trend of Intervals 2-4, not only resulted in the spread of proximal facies toward the depocenter, but also changed the nature of taphonomic processes. Thus, the upward increase in the frequency of Modern shell beds parallels the basin's evolution and points to the possible association between the shell bed styles and lithological changes. The importance of physical factors is further supported by the brief reappearance of Archaic-type shell beds near the top of the Teresina Formation (possibly Interval 4) in the Rio Grande do Sul State (Klein \& Simões 1998). One such shell bed described in detail by Klein \& Simões (1998), a regionally-unique, bivalve-dominated concentration, occurs in offshore deposits that are similar to the distal lithofacies of earlier transgressive phases and that, most likely, record the last high-order transgressive cycle in the Passa Dois Group (Klein 1997). The role of external physical factors is reinforced further by the fact that some distal units of the São Paulo State area can be cross-correlated with the coeval, shallow-water deposits (Sousa et al. 1991, Rohn 1994) characterized by the widespread occurrence of the Modern-type beds. In summary, the upward replacement of the Archaic by the Modern beds may primarily reflect the regressive shift from the distal to the proximal lithologies and taphofacies.

\begin{tabular}{|c|c|c|}
\hline & 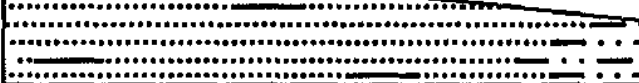 & $\because \div \div \div 2=$ \\
\hline & Terezina/Corumbatai Formation & Serra Alta Formation \\
\hline $\begin{array}{c}\text { Shell-Bed } \\
\text { Characteristics }\end{array}$ & Proximal Tempestite & Distal Tempestite \\
\hline $\begin{array}{c}\text { Biostratinomic } \\
\text { Style }\end{array}$ & Modern Shell-Bed & Archaic Shell-Bed \\
\hline $\begin{array}{l}\text { Taphonomic } \\
\text { Features }\end{array}$ & 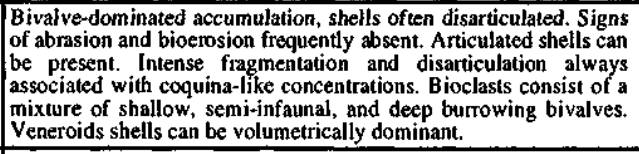 & $\begin{array}{l}\text { Bivalve-dominated concentration. Most shells are } \\
\text { disarticulated but closed and butterflied specimens } \\
\text { occasionally are present. Fragmentation is uncommon. Shells } \\
\text { are often concoidant with the bedding plante. }\end{array}$ \\
\hline $\begin{array}{l}\text { Sedimentologic } \\
\text { Features }\end{array}$ & $\begin{array}{l}\text { Usually loosely to densely packed. Admixtures of siliciclastic } \\
\text { intraclasts can be present especially in lag concentrations. } \\
\text { Discontinuous grading common. }\end{array}$ & $\begin{array}{l}\text { Usually disperse, forming millimeter-scale accumulations. } \\
\text { Rarely loosely packed. }\end{array}$ \\
\hline $\begin{array}{l}\text { Stratigraphic } \\
\text { Features }\end{array}$ & $\begin{array}{l}\text { Multicentimeter-scale lenticular beds with very complex ittemal } \\
\text { fabrics. Some latefally persisitents outerop scale (up } 10.120 \mathrm{~m} \text { ). }\end{array}$ & $\begin{array}{l}\text { Simple internal fabric, some beds locally traceable at outcrop } \\
\text { scale. }\end{array}$ \\
\hline Examples & $\begin{array}{l}\text { Ferraz Shell-Bed; Camaqua Shell-Bed; Tambat Shell-Bed; } \\
\text { concentrations from SP-280 (km 164), 6hin Street; SP-328. Santa } \\
\text { Rita do Passa Quauo. }\end{array}$ & $\begin{array}{l}\text { Concentrations from SP-280 (km } 160 \text { and } 161) \text {, SP-127 (km } \\
10,5 \text { and } 11)\end{array}$ \\
\hline
\end{tabular}


Several lines of evidence suggest that biological factors also played a notable role in controlling the distribution of shell beds. The Modern shell beds vary notably in thickness and taxonomic composition (particularly Intervals 2-4; Tab. 1). This is not surprising given that thick $(30-50 \mathrm{~cm})$ composite shell concentrations are a complex product of multiple episodes of rapid burial, reworking, and winnowing. However, despite that variation, the Modern beds are strikingly uniform in that their bioclasts are invariably dominated by thick and robust shells of infaunal bivalves; including veneroids (Pinzonella, Terraiopsis, Terraia) and megadesmids (Plesiocyprinella, Holdhausielld). Also, all of the thicker coquinas of Modern Type are invariably composed of the low organic (crossed), veneroid shells of Pinzonella illusa and $P$. neotropica. Moreover, although the megadesmids are the most diversified group of bivalves in the Permian sequence of Paraná basin, their aragonitic shells never form densely packed concentrations of Modern type. These data suggest some biologic control (e.g., bivalve shell microstructure, see also Kidwell \& Brenchley 1994, 1996) in the origin of the shell concentrations. Indeed, the opposite taxonomic pattern is shown by the thin, millimeter-scale Archaic concentrations typically dominated by bivalves other than veneroids (Ghilardi 1999).

Long-term trends in bioclastic concentrations The

Modern-type shell beds are usually found in the late Mesozoic and Cenozoic fossil record, while the Archaic-type concentrations dominate the Paleozoic strata (Kidwell 1990, Kidwell \& Brenchley 1994, 1996). The overwhelming dominance of Modern shell beds in the Permian sequences of the Paraná" basin is thus noteworthy. This early onset of Modern-style beds reflects a unique interplay of physical and biological trends. The regional radiation of infaunal bivalves made the Permian macrobenthos of the Paraná basin analogous to the postPaleozoic rather than Paleozoic ecosystems and provided the critical source of durable bioclasts needed for the formation of Modern-type shell concentrations. This regional ecological "revolution" took place in the unique paleogeographic setting of a huge and shallow epeiric sea, where major shifts in the extent of proximal/distal settings controlled the basin-wide taphonomic gradients and determined whether simple or multiple bioclastic concentrations were produced by storms that punctuated monotonous non-bioclastic deposition.

Concluding remarks

The patterns documented here demonstrate that the origin, type and distribution of shell bed concentrations (Archaic vs. Modern mode) can be tied to specific biologic and geologic factors (see also Li \& Droser 1997). As importantly, our data suggest that the transition from the Archaic to Modern type of shell beds and the shift from the Paleozoic to the more modern ecology may have both started already in the late Paleozoic.

Acknowledgements To FAPESP, FUNDUNESP and CNPq for their financial support. This is a contribution to the projects FAPESP 96/9708-9,96/101008-6 and CNPq 301023/94-8. To two anonymous referees of RBG for critical review of the manuscript.

Table 1 - Permian shell concentrations in the Paraná basin

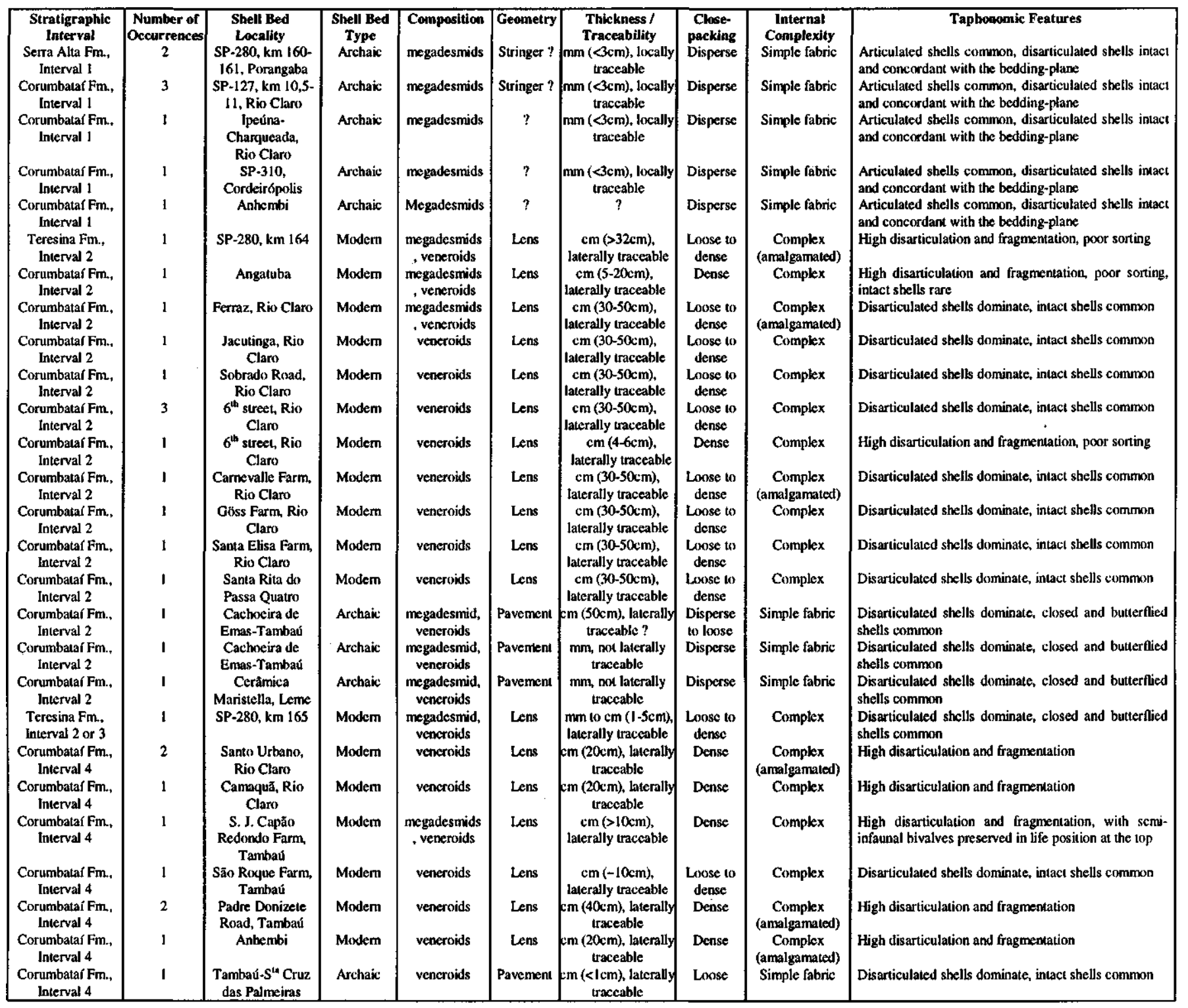




\section{References}

Ghilardi R.P. 1999. Paleoautoecologia dos bivalves do Grupo Passa Dois (Neopermiano): bivalves fósseis como indicadores da dinâmica sedimentar. Inst. de Geociências, Universidade de São Paulo, São Paulo, Unpublished M.Sc. Dissertation, 160p.

Hachiro J. 1996. O Subgrupo Irati (Neopermiano) da Bacia do Paraná, São Paulo. Inst. de Geociências, Universidade de São Paulo, São Paulo, Unpublished Ph.D. Thesis, $192 \mathrm{p}$.

Kidwell S.M. 1990. Phanerozoic evolution of macroinvertebrate shell accumulations: preliminary data from the Jurassic of Great Britain. In: W. W. Miller III (ed.) Paleocommunity Temporal Dynamics. Paleontol. Soc. Spec. Publ, 5: 309-327.

Kidwell S.M. \& Brenchley P.J. 1994. Patterns in bioclastic accumulations through the Phanerozoic: Changes in input or in destruction? Geology, 22:1139-1143.

Kidwell S. M. \& Brenchley P. J. 1996. Evolution of the fossil record: thickness trends in marine skeletal accumulations and their implications. In: Jablonsky D. H., Erwin D. H., Lippis J. H., Brenchley P. J. (eds.) Evolutionary Paleobiology. Chicago, University of Chicago Press, 290-336.

Kidwell S.M. \& Holland S.M. 1991. Field description of coarse bioclastic fabrics. Palaios, 6:426-434.

Kidwell S.M., Fiirsich F. T, Aigner T. 1986. Conceptual framework for the analysis of fossil concentrations. Palaios, 1:228-238.

Klein C. 1997. Contribuição ao estudo das concentrações fossiliferas do Grupo Passa Dois na região de Tiaraju, $R S$ e suas implicações paleoambientais. Centra de Ciencias Tecnológicas, Universidade do Vale do Rio do Sinos, São Leopoldo, RS, Unpublished M.Sc. Dissertation, 153p.

Klein C. \& Simões M. G. 1998. Tafonomia de Pelecípodes da Formação Terezina (Permiano), Tiarajú, RS, Brasil. An. Acad. Bras. Ci., 70:619-625.

Li X \& Droser M. L 1997. Nature and distribution of Cambrian shell concentrations: evidence from the Basin and Range province of western United States (California evidence from the Basin and Range provinc

Matos S.L.F. 1995. O contato entre o Grupo Passa Dois e a Formação Piramboia na borda leste da Bacia do Paraná no Estado de São Paulo. Inst. de Geociểncias, Universi-

dade de São Paulo, São Paulo, Unpublished M.Sc. Dissertation, 1 1Op.

Mello L.H.C. 1999. Análise cladistica dos bivalves do Grupo Passa Dois (Neopermiano) Bacia do Paraná: implicações taxonomicas, evolutivas e paleohiogeogrdficas. Inst. de Geociências, Universidade de São Paulo, São Paulo, Unpublished M.Sc. Dissertation, $160 \mathrm{p}$.

Riccomini C. 1995. Tectonismo gerador e deformador dos depositos sedimentares posgondvânicos da porção centro-leste do Estado de São Paulo e areas vizinhas. Inst. de Geociências, Universidade de São Paulo, São Paulo, Unpublished Full-Professor Thesis, 10Op.
Rohn R. 1994. Evolução amhiental da Bacia do Paraná durante o Neopermiano no leste de Santa Catarina e do Paraná. Inst. de Geociências, Universidade de São Paulo, São Paulo, Unpublished Ph.D. Thesis, $2 \mathrm{v}$.

Santos Neto E.V. \& Cerqueira J.R. 1993. Aplicação da geoquimica orgânica na cronoestratigrafia e paleogeografia da Formação Irati, Bacia do Paraná. In: Simpósio sobre Cronoestratigrafia da Bacia do Paraná 1, Rio Claro, Resumes, 71.

Simões M.G. \& Kowalewski M. 1998. Shell beds as paleoecological puzzles: a case study from the Upper Permian on the Paraná Basin, Brazil. Fades, 38:175-196.

Simões M.G., Torello F.F., Rocha-Campos A.C. $19 \%$. GSnese e classificação da coquina de Camaqua (assembleia de Pinzonella neotropica). Formação Corumbataí (Permiano Superior), Rio Claro, SP. An. Acad. Bras. Ci, 68:545-557.

Simões M.G., Marques A.C., Mello L.H.C., Anelli L.E. 1997. Phylogenetic analysis of the genera of the extinct family Megadesmidae (Pelecypoda, Anomalodesmata), with remarks on its paleoecology and taxonomy. J. Comp. Biol, 2:75-90.

Simões M.G., Rocha-Campos A. C., Anelli L. E. 1998. Paleoecology and evolution of Permian pelecypod assemblages (Paranl Basin) from Brazil. In: P.A. Johnston; J.W. Haggart (eds.) Bivalves - An Eon of evolution - paleobiological studies honoring Norman D. Newell. Calgary, University of Calgary Press, 443-452.

Sohn I.G. \& Rocha-Campos, A.C. 1990. Late Paleozoic (Gondwanian) ostracodes in the Corumbataí Formation, Paraná Basin, Brazil. J. Paleontology, 64:116-128.

Sousa S.H.M. Suguio K. Castro J.C. 1991. Sedimentary facies of the Estrada Nova and Corumbatai Formations (Late Paleozoic of the Parand Basin) in the State of São Paulo, Brazil. In: International Gondwana Symposium, 7, São Paulo, Proceedings, Paulo, Brazil. In: International Gondwana Symposium, 7, São Paulo, Proceedings, 161-172.

Torello F.F. 1999. Caracteristicas tafônomicas das concentrações fossiliferas da Formação Corumbatai (Permiano superior), na região de Tambau, SP, Bacia do Paraná Brasil. Inst. de Geociências, Universidade de São Paulo, São Paulo, Unpublished M.Sc. Dissertation, $130 \mathrm{p}$.

Zalan P. V, Wolff S., Vieira I.S., Astolf M. A., Conceição J.C.J., Zanotto O., Appi V.T. 1991 Tectonics and sedimentation of the Paraná Basin. In: International Gondwana Symposium, 7, São Paulo, Proceedings, 83-117.

Contribution IGC-083

Received February 25,2000 Accepted for publication April 26, 2000 